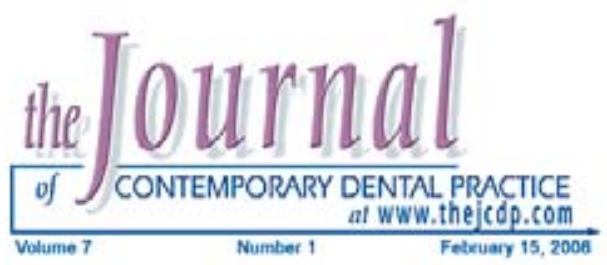

\title{
A Clinical Evaluation of Anorganic Bovine Bone Graft Plus 10\% Collagen with or without a Barrier in the Treatment of Class II Furcation Defects
}

\author{
Krishnanjaneya Pathakota Reddy, BDS; Dilip Gopinath Nayak, MDS; \\ Ashita Sadananda Uppoor A, MDS
}

\begin{abstract}
The use of bone replacement grafts with barrier membranes in class II furcation defects are aimed at improving the outcome of the regenerative technique. In this regard, however, there is a paucity of studies comparing the results obtained with bone grafts alone or in combination with barrier membranes. The aim of this study was to clinically compare an anorganic bovine bone graft plus $10 \%$ collagen (BO) with or without a bioresorbable collagen barrier (BG) in human mandibular molar class II furcation defects.

Methods and Materials: Twenty mandibular class II furcation defects (ten patients with bilateral defects) were treated either with $\mathrm{BO}$ (group I) or a combination of BO/BG (group II). Each defect was randomly assigned to either group I or group II. The soft tissue and hard tissue measurements including vertical probing depth (VPD), horizontal probing depth (HPD), clinical attachment level (CAL), gingival recession $(G R)$, vertical depth of furcation defect (VDF), and horizontal depth of furcation defect (HDF) were recorded at baseline and six months after surgery.
\end{abstract}

(C) Seer Publishing 
Results: Both treatment procedures resulted in statistically significant reduction in VPD and HPD, gain in CAL, and reduction in VDF and HDF. There was a statistically significant difference between group I and group II in all soft and hard tissue parameters with the exception of VPD reduction and gingival recession.

Conclusion: The findings of this study suggest superior clinical results with $\mathrm{BO} / \mathrm{BG}$ treatment when compared to $\mathrm{BO}$ treatment in mandibular class II furcation defects.

Keywords: Furcation defect, regeneration, bovine bone graft, collagen barrier

Citation: Reddy KP, Nayak DG, Uppoor A AS. A Clinical Evaluation of Anorganic Bovine Bone Graft Plus 10\% Collagen with or without a Barrier in the Treatment of Class II Furcation Defects. J Contemp Dent Pract 2006 February;(7)1:060-070.

\section{Introduction}

Management of moderate to advanced furcation invasions presents one of the major challenges in periodontal treatment. Teeth with furcation involvement undergo more extensive and rapid clinical attachment loss and are lost with greater frequency than are single rooted teeth. Class II furcations present a common clinical problem that has perplexed clinicians for many years. Several techniques have been proposed and promoted to treat and improve the prognosis of mandibular class II furcation involved molars.

Gottlow et al. ${ }^{1}$ first reported guided tissue regeneration (GTR) could be favorably employed to regenerate lost periodontal tissues in class Il furcation involvements. To overcome the disadvantages of the non-resorbable barriers (second surgical procedure for membrane removal), the bioresorbable barrier was developed. Problems with barrier membranes have included difficulties in space maintenance of the site and limited bone fill in furcation defects. Alternatively, mandibular molar class II furcation bone replacement grafts have achieved similar results to GTR barriers. ${ }^{2,3,4}$ The use of bone graft materials has been suggested as beneficial with non-resorbable and resorbable barriers. Most reports suggest an enhanced effect of combined therapy in furcation defects. ${ }^{5,6}$

Recent reports in the literature have demonstrated bovine derived anorganic bone xenograft in combination with or without a bioresorbable porcine collagen barrier has supported periodontal regeneration in human intra bony defects and in class II furcation defects. ${ }^{6,7,9}$

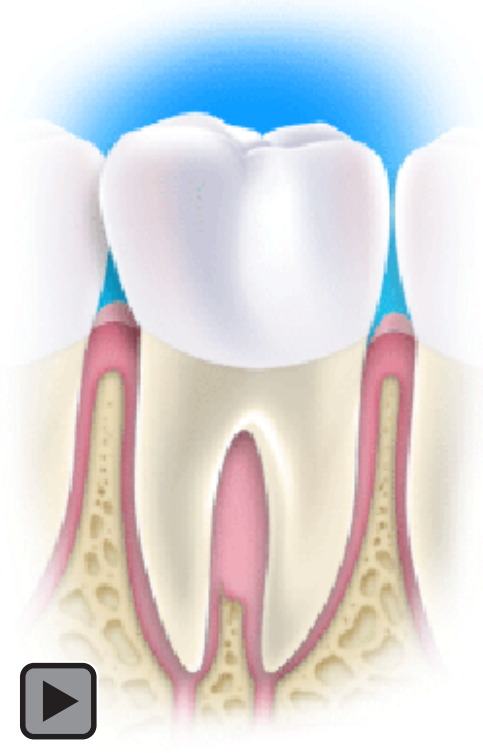

The aim of this study was to compare the clinical attachment gain and the vertical and horizontal furcation bone fill obtained with an anorganic bovine xenograft plus $10 \%$ collagen (BO) [Bio-Oss ${ }^{\circledast} /$ Bio-Oss $^{\circledR}$ COLLAGEN - Geistlich Pharma AG, Switzerland] with or without a porcine bioresorbable collagen barrier (BG) [Bio-Gide ${ }^{\circledR}$ Geistlich Pharma AG, Switzerland] in the treatment of mandibular molar class II furcation defects.

\section{Materials and Methods}

The present study was conducted in the Department of Periodontics, Manipal College of Dental Sciences, Mangalore. Ten systemically healthy patients (eight males and two females, aged 24 to 55 years, with a mean age of 40.2 years) with class II furcation defects (Hamp et al. ${ }^{10}$ classification) in mandibular molars were selected for this study. These patients served as "split 
mouth" candidates, receiving a BO in one defect (group I) and a combination of a BO and a BG on the contralateral side (group II). A thorough medical and dental history was obtained from each patient, and a complete clinical examination including radiographs was performed.

The following criteria were adopted for selecting the patients:

- Exclusion Criteria: Smokers, pregnant patients, a history of previous periodontal surgical treatment, presence of third molars, and untreated non vital teeth.

- Inclusion Criteria: After completion of the initial phase of therapy at base line, the selected mandibular molars should have the following findings: furcation defects with minimum of $3 \mathrm{~mm}$ horizontal probing depth, gingival margin coronal to or at the level of the roof of the furcation, and tooth mobility $\leq$ to grade $\mathrm{I}$.

Written informed consent was obtained from the patient prior to surgery. Each patient was prepared for surgery with an initial phase of therapy including oral hygiene instructions and scaling and root planning. If necessary, occlusal adjustments were done. Approximately four weeks after initial therapy, patients were reevaluated to assess clinical parameters and plaque control. All subjects were required to achieve a minimum of a $20 \%$ plaque index ${ }^{11}$ score prior to progressing to the surgical phase of therapy.

\section{Clinical Measurements and Indices}

Customized acrylic occlusal stents were fabricated on the study casts to serve as a fixed reference point (RP) to take measurements.

The stents were made with prominent mid buccal or mid lingual extensions towards the furcation defect aspect. One vertical groove was prepared in the stent for a reproducible alignment for a periodontal probe. Vertical measurements were taken using the PCP-UNC15 probe (University of North Carolina probe). Horizontal measurements were taken using the curved probe calibrated in $1 \mathrm{~mm}$ increments (Nabers probe). Measurements were rounded off to the nearest millimeter.

\section{Soft and Hard Tissue Measurements}

Soft tissue changes were evaluated byzmeasuring clinical attachment level, reduction in probing depth, and gingival recession. The apical end of the vertical groove of the stent was used as a RP.

1. Vertical probing depth (VPD) was recorded using a UNC-15 probe by noting the difference between measurements from the RP to gingival margin (GM), minus RP to base of the pocket (BOP).

2. Clinical attachment level (CAL) at the furcation defect was calculated by subtracting the distance between the RP to the cementoenamel junction (CEJ) and the distance between the RP to the BOP.

3. Horizontal probing depth at furcation defect (HPD) was measured using curved probe with $1 \mathrm{~mm}$ markings (Nabers probe). As reference, a tangent to the roots adjacent to the scored furcation was used.

4. Gingival recession ( $G R=R P$ to $G M-R P$ to CEJ).

The following soft tissue measurements were taken along with the above mentioned measurements after six months, i.e., clinical attachments gain, VPD reduction, and HPD reduction.

\section{Hard Tissue Measurements}

Hard tissue measurements were taken at base line through bone sounding (probing bone level measurements) and via surgical entry (open bone level measurements). At six months post surgery, hard tissue measurements were taken through bone sounding only. Hard tissue changes were evaluated by using probing bone level measurements. At base line, probing bone level measurements and open bone level measurements were compared.

\section{Probing Bone Level Measurements}

The hard tissue measurements were obtained immediately following local anesthesia by forcing the probe through the soft tissues until definite resistance was met.

Vertical depth of the furcation defect (VDF-P): i.e., from the fornix of furcation (FF) to the base of the bony defect (BOD) (VDF-P=RP to BOD-RP to FF) (Figures 1a and 2a). Horizontal depth of the furcation defect (HDF-P): i.e., from a tangent to the roots adjacent to the furcation (TF) to the horizontally deepest part of the defect (HF). (HDF$\mathrm{P})=\mathrm{RP}$ to HF-RP to TF) (Figures $1 \mathrm{~b}$ and $2 \mathrm{~b}$ ). 


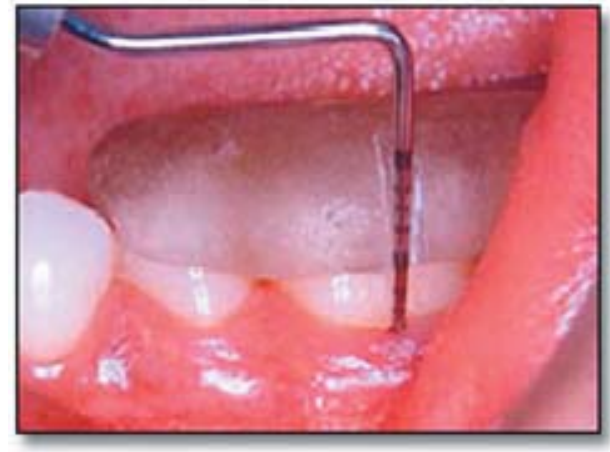

Figure 1a. Group I, tooth \#36 pre-operative vertical probing bone level.

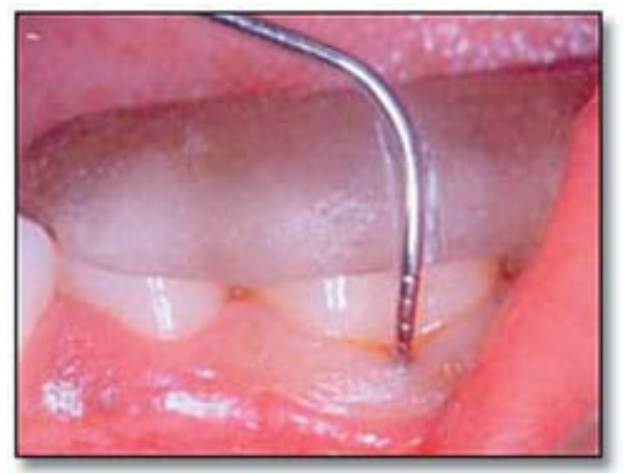

Figure 1b. Group I, tooth \#36 pre-operative horizontal probing bone level.

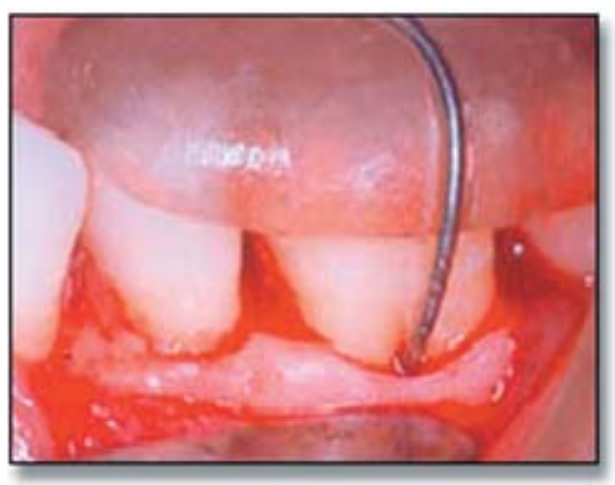

Figure 1c. Group I, tooth \#36 horizontal open probing bone level.

\section{Open Bone Level Measurements}

Open furcation bone level measurements were taken during surgery before placement of implant materials. Vertical depth of furcation defect (VDF$\mathrm{O}=\mathrm{RP}$ to BOD-RP to FF). Horizontal depth of furcation defect (HDF-O=RP to HF-RP to TF) (Figures 1c and 2c).

The following hard tissue parameters were taken after six months post surgery along with the above mentioned probing bone measurements,

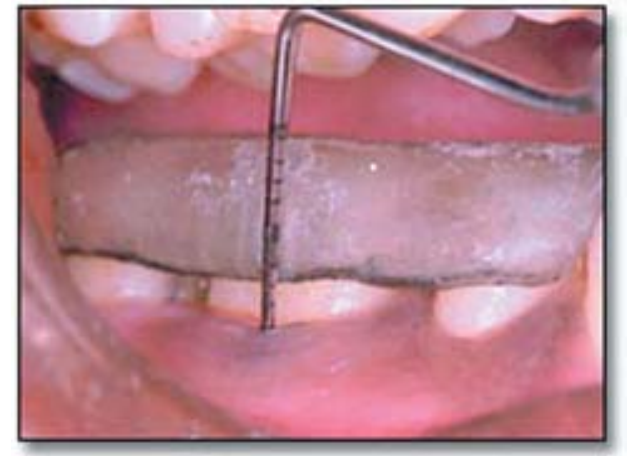

Figure 2a. Group II, tooth \#46 pre-operative vertical probing bone level.

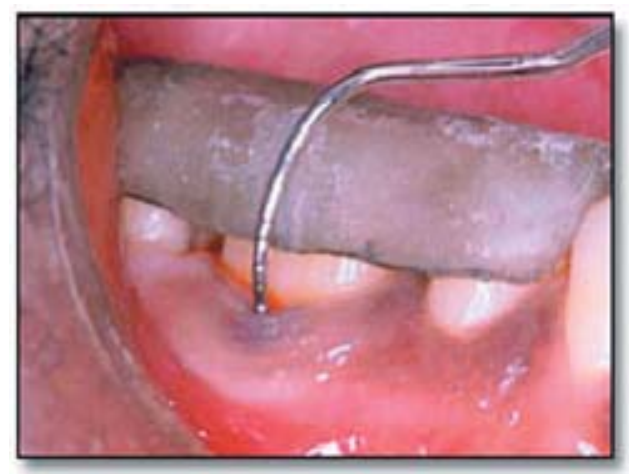

Figure 2b. Group II, tooth \#46 pre-operative horizontal probing bone level.

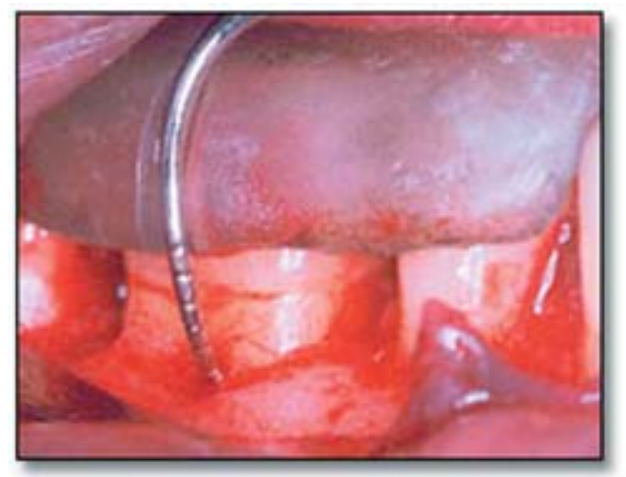

Figure 2c. Group II, tooth \#46 horizontal open probing bone level.

i.e., vertical furcation bone fill in $\mathrm{mm}$, horizontal furcation bone fill in $\mathrm{mm}$, and percentage bone fill (percentage of vertical and horizontal furcation bone fill).

Plaque index ${ }^{12}$ and gingival index ${ }^{13}$ were recorded at base line, three months, and six months post operatively. Intra oral radiographs were taken with Kodak D speed film using a Rinn XCP device with the long cone paralleling technique at base line and six months post surgically. 


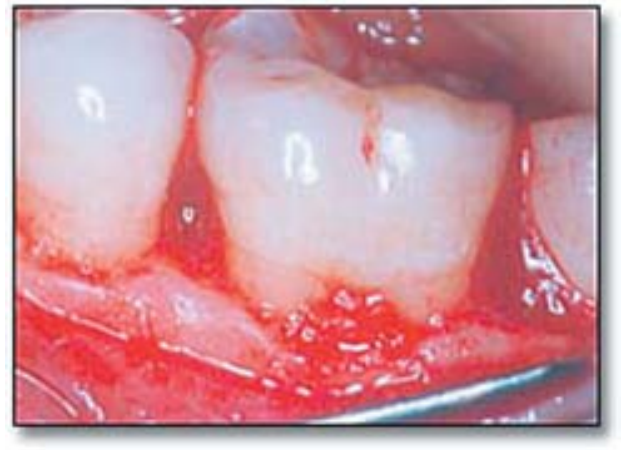

Figure 1d. Group I, the BO placed into tooth \#36 buccal furcation defect.

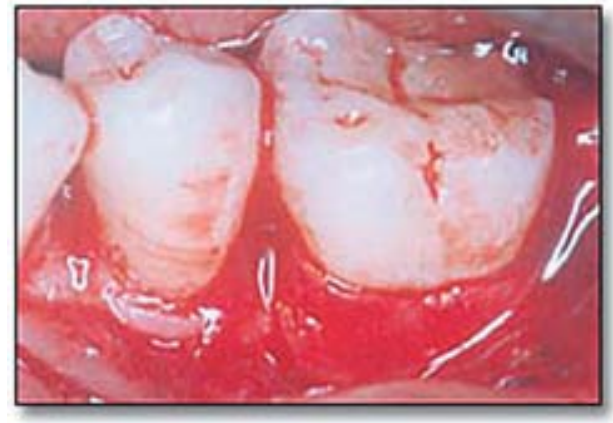

Figure 1e. Group I, the BG tightly adhered to bone and tooth after applying pressure.

\section{Surgical Protocol}

Following data collection, the decision to use a combination of BOand BG or BO was determined by a coin toss. The surgical area was anesthetized using Xylocaine $2 \%$ with 1 : 200,000 epinehrine. Sulcular incisions and fullthickness flaps were used to retain sufficient tissue to obtain primary closure. Furcation defects were thoroughly scaled and root planed with hand instruments and ultrasonic scalers. Enamel projections, if noted, were removed using a bur with a high-speed rotary instrument. Root conditioning was not used in this study.

The furcation was completely filled with BO (Figures 1d and 2d).

The BO was cut with tweezers and scissors in dry form. The material was applied with tweezers into the defect and it was not over filled. The $B G$ was trimmed to adapt to the furcation region. The margins of the barrier were extended 3 to $5 \mathrm{~mm}$ beyond the defect onto the alveolar bone for stability. The dense surface marked at the membrane margin with $<<U P>>$ faced the soft tissue and the rough side faced the bone. The

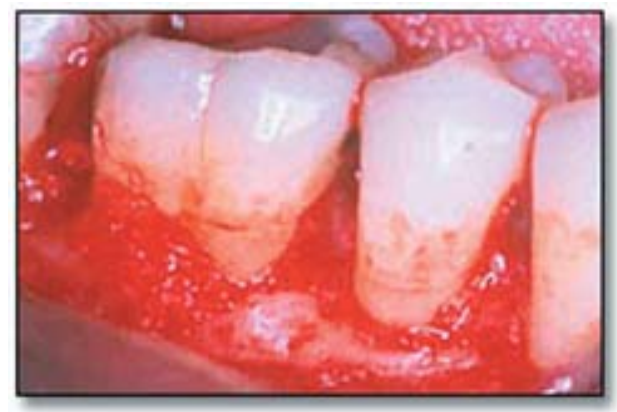

Figure 2d. Group II, the BO placed into tooth \#46 buccĈ̣" ŸQmition defect.

membrane was applied over the defect without further treatment and held in place with moderate pressure (Figure 1e).

The period of time necessary to apply pressure varied with the degree of bleeding. Adherence to the bone surface was achieved by gel formation of the collagen fibers with blood. Due to the high tensile strength of this membrane, fixation was possible. Hence, no stabilizing sutures were required. Primary soft tissue closure was obtained with 4-0 black silk sutures in an interrupted manner.

Patients were prescribed $100 \mathrm{mg}$ of doxycycline daily for ten days, ibuprofen 800 mg every eight hours, as needed, for pain, and $0.2 \%$ chlorhexidine gluconate twice daily for four weeks post surgically to aid in plaque suppression. The patients were asked to refrain from mechanical plaque control for four weeks at the surgical site. Sutures were removed after seven days. Post operative appointments were conducted at seven, 14, and 21 days and one, three, and six months. At six months post surgically, both hard tissue and soft tissue measurements were taken (Figures 1f, 1g, 2e, and 2f).

\section{Statistical Analysis}

Both hard tissue and soft tissue parameters were obtained at the base line and at six months post operatively. Microsoft excel spread sheet program and ARCUS Pro-Stat version 3.23 was used for statistical analysis. A paired student's $\mathrm{t}$ test was used to evaluate differences within group I and group II from baseline to six months post operatively. An unpaired student's t test was used to compare group I and group II. 


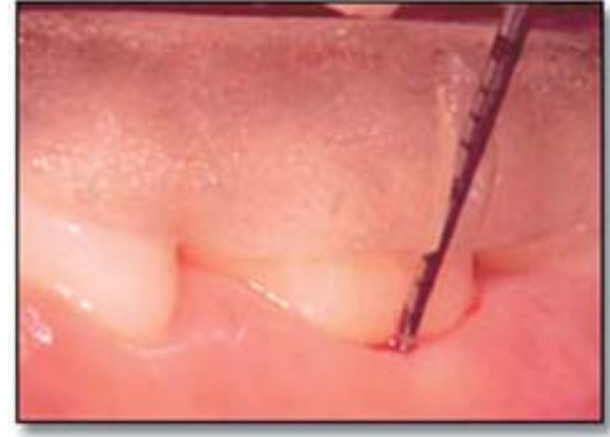

Figure 1f. Group I, tooth \#36 post-operative vertical probing bone level.

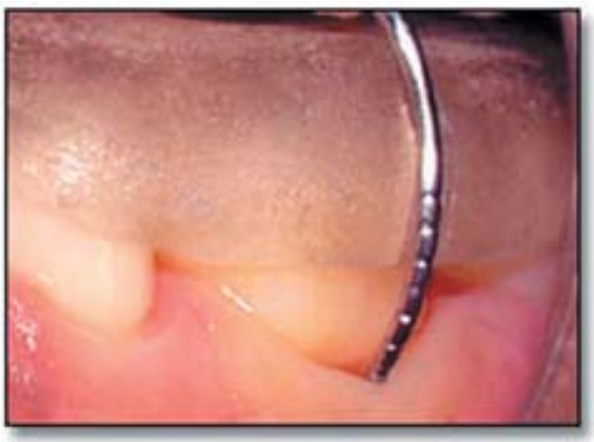

Figure 1g. Group I, tooth \#36 post-operative horizontal probing bone level.

\section{Results}

All patients showed good compliance, and the healing period was uneventful for both treatment groups without infection or complications. Base line analysis showed no significant differences between group I and group II for any of the variables assessed, suggesting that final differences between treatments were not influenced by initial defect characteristics, thus, allowing post treatment results to be compared.

Changes in soft tissue and hard tissue parameters at six month post operatively for group I, group II, and a comparison between both the groups are presented in Tables 1, 2, and 3. The mean percentage of vertical and horizontal defect resolution was calculated for both group I and group II (Figures 3 and 4).

The number of furcation sites according to Hamp et al. ${ }^{10}$ and Tarnow and Fletcher ${ }^{13}$ classification at base line and at six months post operatively is presented in Table 4.

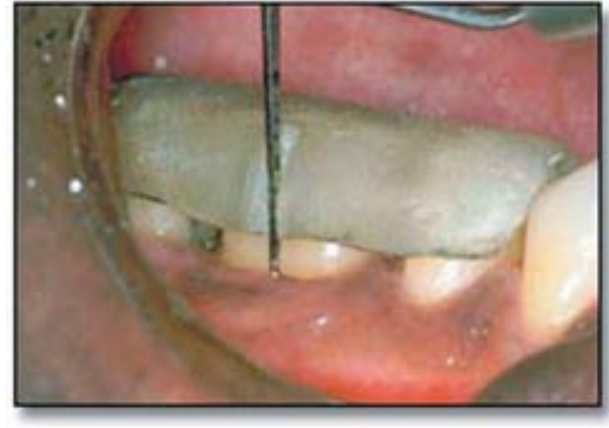

Figure 2e. Group II, tooth \#46 post-operative vertical probing bone level.

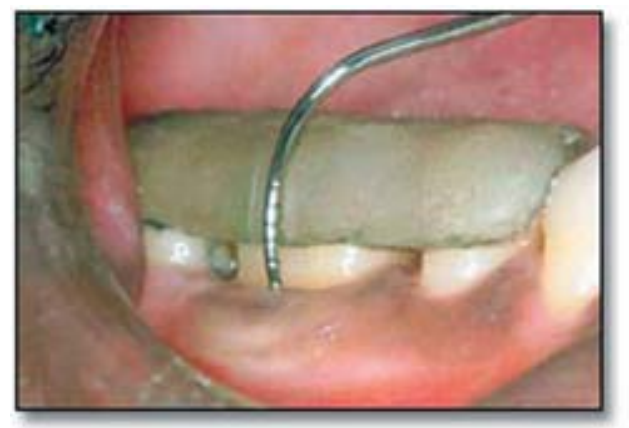

Figure 2f. Group II, tooth \#46 post-operative horizontal probing bone level.

For all the patients, mean plaque index ${ }^{12}$ and gingival index ${ }^{13}$ were reduced from base line to six months post operatively (Table 5). Comparison of probing bone level measurements (bone sounding measurements) and open bone level measurements (surgical entry measurements) at base line revealed a statistically significant correlation between horizontal and vertical depth of furcation defect through bone sounding and through surgical entry (Table 6).

\section{Discusssion}

A multitude of new materials are being tested for promoting periodontal regeneration in furcation defects. Recent reports in the literature have demonstrated bovine derived anorganic bone xenograft (Bio-Oss ${ }^{\circledR} /$ Bio-Oss $^{\circledR}$ COLLAGEN) in combination with or without a bioresorbable porcine collagen barrier (Bio-Gide ${ }^{\circledR} /$ Bio-Gide $^{\circledR}$ PERIO) have supported periodontal regeneration in human intrabony defects and in class II furcation defects. ${ }^{6,7,8,9}$ 
Table 1. Results of treatment with BO (group I).

\begin{tabular}{|l|c|c|c|c|}
\hline & $\begin{array}{c}\text { Base line } \\
\text { Mean } \pm \text { SD } \\
(\mathrm{mm})\end{array}$ & $\begin{array}{c}6 \text { months } \\
\text { post-operative } \\
\text { Mean } \pm \text { SD } \\
(\mathrm{mm})\end{array}$ & $\begin{array}{c}\text { Difference } \\
\text { Mean } \pm \text { SD } \\
(\mathrm{mm})\end{array}$ & p value \\
\hline $\begin{array}{l}\text { Probing } \\
\text { Depth (PD) }\end{array}$ & $5.30 \pm 0.95$ & $3.20 \pm 0.42$ & $2.10 \pm 0.74$ & $p<0.0001^{*}$ \\
\hline $\begin{array}{l}\text { Clinical } \\
\text { Attachment } \\
\text { Level } \\
\text { (CAL) }\end{array}$ & $6.00 \pm 1.15$ & $4.20 \pm 0.79$ & $1.80 \pm 0.63$ & $p<0.0001^{*}$ \\
\hline $\begin{array}{l}\text { Gingival } \\
\text { Recession } \\
\text { (GR) }\end{array}$ & $0.70 \pm 0.95$ & $1.00 \pm 0.82$ & $-0.30 \pm 0.48$ & $p>0.05$ \\
\hline $\begin{array}{l}\text { Horizontal } \\
\text { Probing } \\
\text { Depth } \\
\text { (HPD) }\end{array}$ & $4.00 \pm 1.05$ & $1.80 \pm 0.79$ & $2.20 \pm 0.63$ & $p<0.0001 *$ \\
\hline $\begin{array}{l}\text { Vertical } \\
\text { depth of } \\
\text { furcation } \\
\text { defect } \\
\text { (VDF) }\end{array}$ & $4.70 \pm 0.95$ & $3.10 \pm 0.99$ & $1.60 \pm 0.52$ & $p<0.0001 \cdot$ \\
\hline $\begin{array}{l}\text { Horizontal } \\
\text { depth of } \\
\text { furcation } \\
\text { defect } \\
\text { (HDF) }\end{array}$ & $5.20 \pm 1.14$ & $2.80 \pm 0.79$ & $2.40 \pm 0.70$ & $p<0.0001 *$ \\
\hline
\end{tabular}

*Statisticly Significant

Table 2. Results of treatment with BO/BG (group II).

\begin{tabular}{|l|c|c|c|c|}
\hline & $\begin{array}{c}\text { Base line } \\
\text { Mean } \pm \text { SD } \\
(\mathrm{mm})\end{array}$ & $\begin{array}{c}6 \text { months } \\
\text { post-operative } \\
\text { Mean } \pm \text { SD } \\
(\mathrm{mm})\end{array}$ & $\begin{array}{c}\text { Difference } \\
\text { Mean } \pm \text { SD } \\
(\mathrm{mm})\end{array}$ & p value \\
\hline $\begin{array}{l}\text { Probing } \\
\text { Depth (PD) }\end{array}$ & $5.20 \pm 1.03$ & $2.60 \pm 0.70$ & $2.60 \pm 0.70$ & $p<0.0001^{*}$ \\
\hline $\begin{array}{l}\text { Clinical } \\
\text { Attachment } \\
\text { Level } \\
\text { (CAL) }\end{array}$ & $5.80 \pm 1.23$ & $3.30 \pm 0.95$ & $2.50 \pm 0.71$ & $p<0.0001^{*}$ \\
\hline $\begin{array}{l}\text { Gingival } \\
\text { Recession } \\
\text { (GR) }\end{array}$ & $0.60 \pm 0.97$ & $0.70 \pm 0.95$ & $-0.10 \pm 0.32$ & $p>0.05$ \\
\hline $\begin{array}{l}\text { Horizontal } \\
\text { Probing } \\
\text { Depth } \\
\text { (HPD) }\end{array}$ & $4.10 \pm 0.32$ & $1.00 \pm 0.67$ & $3.10 \pm 0.57$ & $p<0.0001 *$ \\
\hline $\begin{array}{l}\text { Vertical } \\
\text { depth of } \\
\text { furcation } \\
\text { defect } \\
\text { (VDF) }\end{array}$ & $4.60 \pm 0.84$ & $1.90 \pm 1.10$ & $2.70 \pm 0.67$ & $p<0.0001 \cdot$ \\
\hline $\begin{array}{l}\text { Horizontal } \\
\text { depth of } \\
\text { furcation } \\
\text { defect } \\
\text { (HDF) }\end{array}$ & $5.40 \pm 0.52$ & $2.00 \pm 0.82$ & $3.40 \pm 0.84$ & $p<0.0001 \cdot$ \\
\hline
\end{tabular}

*Statisticly Significant 
Table 3. Comparison of soft tissue and hard tissue results of group I and group II at six months post-operative.

\begin{tabular}{|c|c|c|c|c|}
\hline Parameter & $\begin{array}{c}\text { Group I } \\
\text { Mean } \pm \mathrm{SD}(\mathrm{mm})\end{array}$ & $\begin{array}{l}\text { Group II } \\
\text { Mean } \pm \\
\text { SD }(m m)\end{array}$ & $\begin{array}{c}\text { Difference } \\
\text { Mean } \pm \\
\mathrm{SD}(\mathrm{mm})\end{array}$ & p value \\
\hline $\begin{array}{l}\text { Probing Depth } \\
\text { (PD) }\end{array}$ & $2.10 \pm 0.74$ & $2.60 \pm 0.70$ & $0.50 \pm 0.72$ & $p>0.05$ \\
\hline $\begin{array}{l}\text { Clinical } \\
\text { Attachment } \\
\text { Level (CAL) }\end{array}$ & $1.80 \pm 0.63$ & $2.50 \pm 0.71$ & $0.70 \pm 0.67$ & $p<0.05^{\circ}$ \\
\hline $\begin{array}{l}\text { Gingival } \\
\text { Recession (GR) }\end{array}$ & $-0.30 \pm 0.48$ & $-0.10 \pm 0.32$ & $-0.2 \pm 0.40$ & $p>0.05$ \\
\hline $\begin{array}{l}\text { Horizontal } \\
\text { Probing Depth } \\
\text { Reduction(HPD) }\end{array}$ & $2.20 \pm 0.63$ & $3.10 \pm 0.57$ & $0.90 \pm 0.60$ & $p<0.05^{\circ}$ \\
\hline $\begin{array}{l}\text { Vertical depth } \\
\text { of furcation } \\
\text { defect (VDF) }\end{array}$ & $1.60 \pm 0.52$ & $2.70 \pm 0.67$ & $1.10 \pm 0.59$ & $p<0.001^{\circ}$ \\
\hline $\begin{array}{l}\text { Horizontal depth } \\
\text { of furcation } \\
\text { defect (HDF) }\end{array}$ & $2.40 \pm 0.70$ & $3.40 \pm 0.84$ & $1.00 \pm 0.80$ & $p<0.05^{\circ}$ \\
\hline
\end{tabular}

*Statisticly Significant

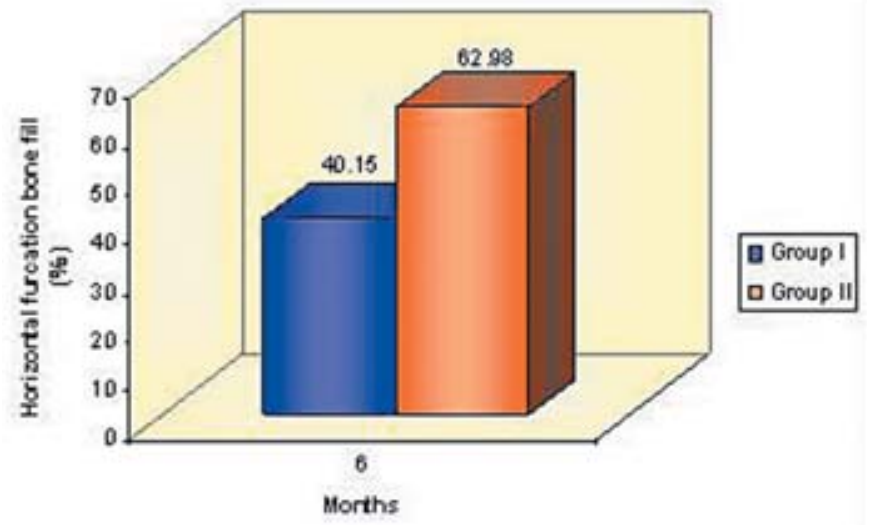

Figure 3. Mean percentage vertical furcation. Postoperative bone fill for group I and group II at six months.

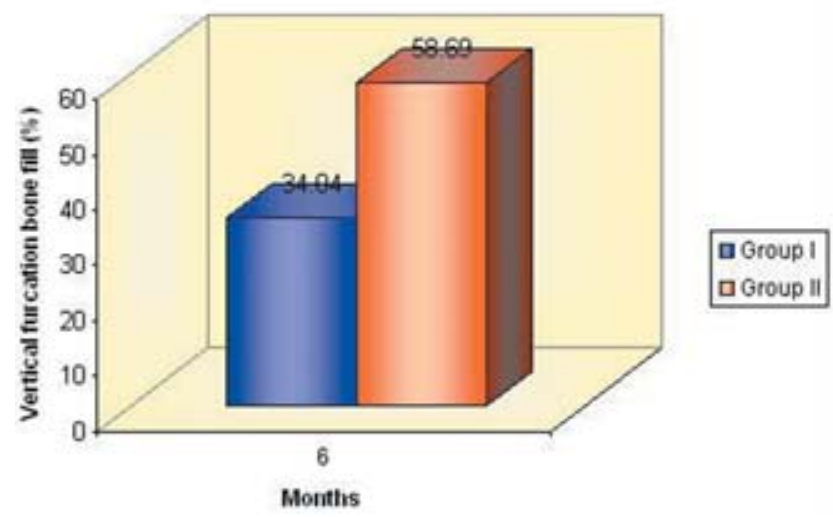

Figure 4. Mean percentage horizontal furcation. Postoperative bone fill for group I and group II at six months. 
Table 4. Number of group I and group II furcation sites according to Hamp et al. and Tarnow and Fletcher classification at base line and six months postoperative.

\begin{tabular}{|c|c|c|c|c|}
\hline \multirow[b]{2}{*}{ Classification } & \multicolumn{2}{|c|}{ Group I } & \multicolumn{2}{|c|}{ Group II } \\
\hline & Base line & $\begin{array}{l}6 \text { months Post } \\
\text { Operatively }\end{array}$ & Base line & $\begin{array}{l}6 \text { months Post- } \\
\text { operative }\end{array}$ \\
\hline $\begin{array}{l}\text { Complete } \\
\text { furcation } \\
\text { closure }\end{array}$ & 0 & 0 & 0 & 1 \\
\hline $\begin{array}{l}\text { Hamp et al } \\
\text { [Horizontal] } \\
\text { Class I (< } \\
3 \mathrm{~mm})\end{array}$ & 0 & 8 & 0 & 9 \\
\hline $\begin{array}{l}\text { Class II ( >3 } \\
\mathrm{mm})\end{array}$ & 10 & 2 & 10 & 0 \\
\hline $\begin{array}{l}\text { Class III } \\
\text { (Through and } \\
\text { through) }\end{array}$ & 0 & 0 & 0 & 0 \\
\hline $\begin{array}{l}\text { Tarnow and } \\
\text { Fletcher } \\
\text { (vertical) } \\
\text { Sub class A ( } \\
1-3 \mathrm{~mm} \text { ) }\end{array}$ & 1 & 7 & 0 & 8 \\
\hline $\begin{array}{l}\text { Sub class B ( } \\
4-6 \mathrm{~mm} \text { ) }\end{array}$ & 9 & 3 & 10 & 1 \\
\hline $\begin{array}{l}\text { Sub class C } \\
(>7 \mathrm{~mm})\end{array}$ & 0 & 0 & 0 & 0 \\
\hline
\end{tabular}

Table 5. Mean plaque and gingival indices score at base line and six months postoperative.

\begin{tabular}{|l|c|c|c|c|c|}
\hline \multicolumn{1}{|c|}{ Index } & $\begin{array}{c}\text { Base line } \\
\text { Mean } \pm \text { SD }\end{array}$ & $\begin{array}{c}3 \text { months } \\
\text { Post } \\
\text { Operative } \\
\text { Mean } \pm \text { SD }\end{array}$ & $\begin{array}{c}6 \text { months } \\
\text { Post } \\
\text { Operative } \\
\text { Mean } \pm \text { SD }\end{array}$ & $\begin{array}{c}\text { Base line Vs } \\
3 \text { months } \\
\text { p value }\end{array}$ & $\begin{array}{c}\text { Baselline } \\
\text { Vs 6 } \\
\text { months } \\
\text { p value }\end{array}$ \\
\hline $\begin{array}{l}\text { Plaque } \\
\text { Index [P] }\end{array}$ & $0.15 \pm 0.02$ & $0.12 \pm 0.03$ & $0.12 \pm 0.02$ & $p<0.05^{*}$ & $p<0.05^{*}$ \\
\hline $\begin{array}{l}\text { Gingival } \\
\text { Index [G] }\end{array}$ & $0.14 \pm 0.02$ & $0.13 \pm 0.02$ & $0.12 \pm 0.03$ & $p<0.05^{*}$ & $p<0.05^{*}$ \\
\hline
\end{tabular}

*Statisticly Significant

Table 6. Comparision of probing bone level measurements vs open bone level measurements at base line.

\begin{tabular}{|l|c|c|c|c|}
\hline & $\begin{array}{c}\text { Probing bone } \\
\text { level } \\
\text { measurements } \\
\text { MeantSD }(\mathrm{mm})\end{array}$ & $\begin{array}{c}\text { Open bone } \\
\text { level } \\
\text { measurements } \\
\text { MeantSD }(\mathrm{mm})\end{array}$ & $\begin{array}{c}\text { Difference } \\
\text { MeantSD } \\
(\mathrm{mm})\end{array}$ & $\begin{array}{c}\text { Correlation } \\
\text { Coefficlent }(\mathrm{r})\end{array}$ \\
\hline $\begin{array}{l}\text { Vertical Depth } \\
\text { of Furcation } \\
\text { Defect (VDF) }\end{array}$ & $4.65 \pm 0.87$ & $4.75 \pm 0.88$ & $0.10 \pm 0.45$ & $0.952 \cdot$ \\
\hline $\begin{array}{l}\text { Horizontal } \\
\text { Depth of } \\
\text { furcation } \\
\text { defect (HDF) }\end{array}$ & $5.3 \pm 0.75$ & $5.5 \pm 0.93$ & $0.2 \pm 0.67$ & $0.925 \cdot$ \\
\hline
\end{tabular}

*Statisticly Significant 
In the present study furcation defects treated with a BO, i.e., group I showed a statistically significant improvement in soft tissue parameters such as VPD reduction, gain in CAL, and HPD reduction (Table 1). These results are in agreement with results observed in Evans et al. ${ }^{2}$, Gantes et al. ${ }^{3}$, Yukna et al. ${ }^{4}$, and Rosen et al. ${ }^{5}$ studies while using bone replacement grafts in furcation defects.

Similarly, furcation defects treated with a combination of BO and BG, i.e., group II, showed a statistically significant improvement in soft tissue parameters (Table 2).

These results are in agreement with the results observed in Houser et al. ${ }^{6}$ study while using an anorganic bovine bone graft (Bio-Oss ${ }^{\circledR}$ ) and a bioresorbable collagen barrier in class II furcation defects.

Gingival recession in group II was less. Limited soft tissue recession may be attributed to the handling characteristics of the BG barriers. Once hydrated in blood or saline, the barrier becomes malleable and memory free and can be easily adapted to the furcation defect, bone graft, and interproximal areas. Once tucked under the apical border of the flap, the barrier adheres to the alveolar bone and implanted bone graft. No sutures are required to stabilize the barrier.

The hard tissue changes were evaluated using probing bone level measurements (bone sounding measurements). Although surgical entry is the most accurate method to assess hard tissue changes, it may cause discomfort to the patient and possibly some damage to the regenerated tissue. Therefore, probing bone level measurements have been introduced and found to be reliable to evaluate hard tissue changes
(Zybutz et al. $2000^{15}$ and Suh et al. $2002^{16}$ ). In the present study comparison between probing bone level measurements and open bone level measurements (surgical entry) at base line showed a statistically significant correlation between the two measurements (Table 6).

Group I showed a statistically significant improvement in hard tissue parameters such as vertical and horizontal furcation bone fill (Table 1). These results are in agreement with results observed in Evans et al. ${ }^{2}$, Gantes et al. ${ }^{3}$, Yukna et al. ${ }^{4}$, and Rosen et al. ${ }^{5}$ studies while using bone replacement grafts in furcation defects. Similarly, group II showed a statistically significant improvement in hard tissue parameters (Table 2). These results are in agreement with results observed in Houser et al. ${ }^{6}$ and Rosen et al. ${ }^{5}$ studies while using a combination of bioresorbable barriers and bone grafts in furcation defects.

Furcation defects treated with BO/BG (group II) showed better clinical improvements than group I. These results may be attributed to several factors such as bone graft containment with BG barriers, the GTR effect of BG, space maintaining capacity of $\mathrm{BO}$ underneath the $\mathrm{BG}$ barrier, and greater bone formation induced by BO/BG combination.

\section{Conclusion}

In view of these findings it can be concluded both a BO with or without a $B G$ is effective in the treatment of mandibular class II furcation defects. The combination of BO and BG led to better results in both soft tissue and hard tissue parameters. Future studies using these materials are needed to determine the predictability of the regenerative response in a furcation environment. 


\section{References}

1. Gottlow J. Periodontol regeneration. Proceedings of the first European workshop in Periodontology.London; Quintessence, 1994:172-192.

2. Evans GH, Yukna RA, Sepe WW, et al. Effect of various graft materials with tetracycline in localized juvenile periodontitis. J Periodontol 1989;60:491-197.

3. Gantes B, Martin M, Garrett S, et al. Treatment of periodontal defects. II. Bone regeneration in mandibular classll defects. J Clin Periodontol 1988; 15: 232-239.

4. Yukna RA, Evans GH, Ridy MB, et al. Clinical comparison of Bioactive glass bone replacement graft material and expanded polytetrafluoroethylene barrier membrane in treating mandibular molar class II furcations. J Periodontol 2001; 72: 125-133.

5. Rosen PS. The clinical evaluation of graft enhancement: A study of periodontal regeneration utilizing a combination of DFDBA and Gore-tex membrane in mandibular classll furcations. Thesis; University of Maryland;1989.

6. Houser BE, Mellonig JT, Brunsvold MA, et al. Clinical evaluation of a anorganic bovine bone xenograft with a bioresorbable collagen barrier in the treatment of molar furcation defects. Int $\mathrm{J}$ Periodontics Restorative Dent 2001; 12:161-169.

7. Camelo M, Nevins ML, Schenk RK, et al. Clinical, radiographic and histologic evaluation of human periodontal defects treated with Bio-Oss and Bio-Guide. Int J Periodontics Restorative Dent 1998; 18: 3-13.

8. Camelo M, Nevins ML, Lynch SE, et al. Periodontol regeneration with an autogenous bone-Bio-Oss composite graft and a Bio-Guide membrane. Int J Periodontics Restorative Dent 2001; 12: 109-119.

9. Nevins ML, Camelo M, Lynch SE, et al. Evaluation of Periodontol regeneration following grafting intrabony defects with Bio-Oss Collagen. A human histologic report. Int J Periodontics Restorative Dent 2003; $23: 9-17$.

10. Carnevale G, Pontoriero R, Lindhe J. Treatment of furcation involved teeth. In : Lindhe J, Karring T, Lang NP, ed. Clinical periodontology and implant dentistry, 3rd edition, Copenhagen, Munksgaard, $1997: 682-710$.

11. O'Leary TJ, Drake RB, Naylor JE. The plaque control record. J Periodontol 1972;43:38.

12. Silness $\mathrm{J}$, Loe H. Periodontol disease in pregnancy II. Correlation between oral hygiene and periodontal condition. Acta Odontol Scand 1964;22:121-135.

13. Loe H, Silness J. Periodontol disease in pregnancy. I.Prevalence and severity. Acta Odontol Scand 1963;21: 533-541.

14. Tarnow D, Fletcher P. Classification of vertical component of furcation involvement. J Periodontol 1984; 55 : 283-284.

15. Zybutz M, Rapoport D, Laurell Lo, et al. Comparison of clinical and radiographic measurements of interproximal vertical defects before and 1 year after surgical treatments.J Clin Periodontol 2000;27: 179-186.

16. Suh Y-II, Lundgren T, Sigurdsson T, et al. Probing bone level measurements for determination of the depths of class II furcation defects. J Periodontol 2002; $73: 637-642$. 


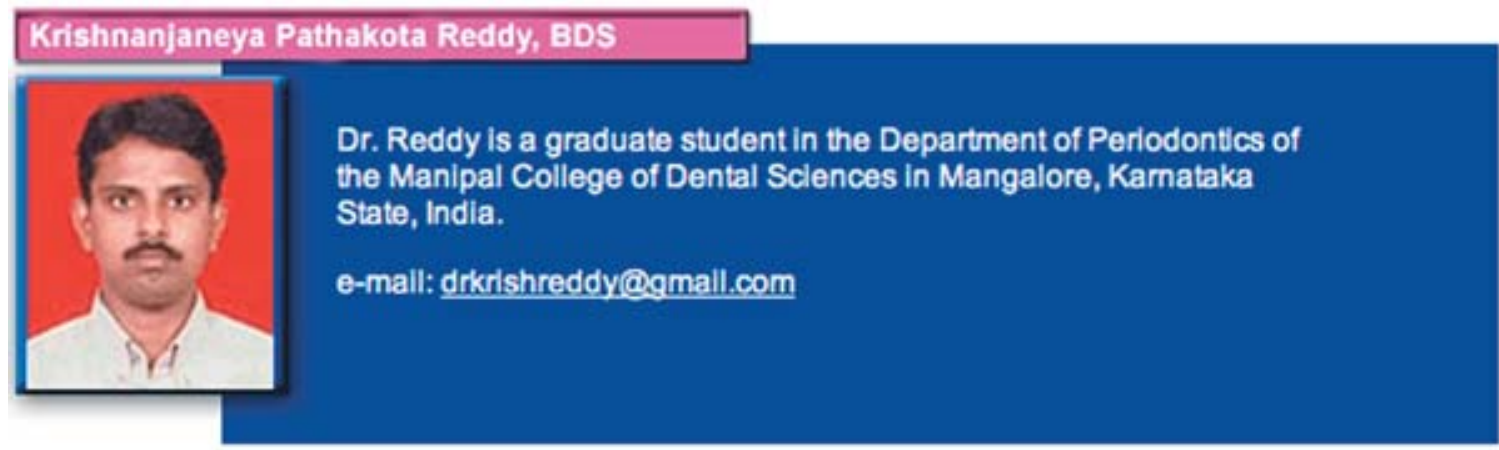

\section{Dillp Gopinath Nayak, MDS}

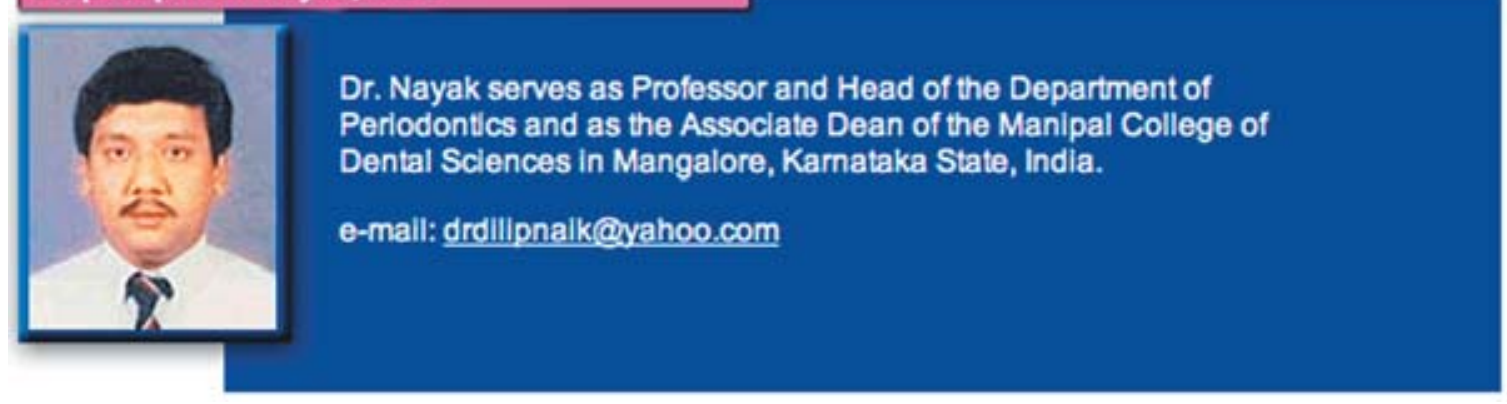

\section{Ashita Sadananda Uppoor A, MDS}

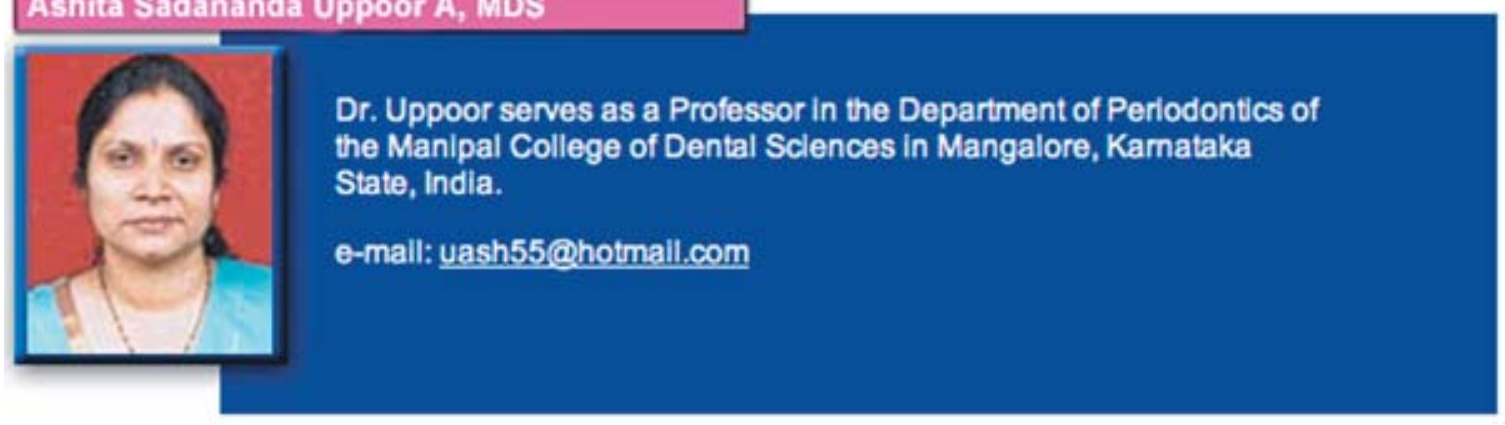

\section{Acknowledgements}

The authors wish to thank Dr. Vani C and Dr. Vineet Kini for support of this study and to Dr. Srinivas K.S and Dr. Pavan Kancherla for assistance during manuscript preparation. 